\title{
DISTRIBUIÇÃO ESPACIAL DO Mycobacterium bovis NO NORDESTE DO ESTADO DE SÃO PAULO
}

\author{
Mycobacterium bovis SPATIAL DISTRIBUTION IN NORTHEAST OF \\ SÃO PAULO STATE
}

\author{
M. J. L. SICONELLII ${ }^{11 *}$, D. A. V. SILVA ${ }^{2}$, K. P. BÜRGER ${ }^{3}$
}

\begin{abstract}
RESUMO
O uso de técnicas de análise espacial na Saúde Pública é o ponto de partida para que se possa compreender o perfil epidemiológico das enfermidades. Além disso, o geoprocessamento na saúde é importante na avaliação de riscos à saúde coletiva e também para entender a dinâmica da distribuição de doenças. O objetivo foi realizar o geoprocessamento dos municípios de origem dos bovinos considerados positivos para tuberculose bovina pelo cultivo microbiológico, caracterização histopatológica, identificação de bacilos álcool-ácido resistentes e pela detecção molecular do M. bovis pela PCR a partir de DNA extraído das lesões sugestivas de tuberculose e das colônias bacterianas isoladas. Foram identificadas e coletadas 50 amostras de linfonodos de bovinos com lesões sugestivas de tuberculose, abatidos sob Serviço de Inspeção Federal em matadouros-frigoríficos da região nordeste do Estado de São Paulo, entre os meses de Julho de 2013 e Julho de 2014. Para análise dos dados foi utilizado o software TerraView 4.2.2. Houve dependência espacial entre a localização dos municípios e a ocorrência de tuberculose em todos os diagnósticos estudados quando avaliados separadamente, exceto na detecção do M. bovis pela PCR nas lesões sugestivas de tuberculose. Não houve dependência espacial quando todos os métodos diagnósticos foram avaliados concomitantemente. A dependência espacial entre a localização dos municípios e a ocorrência de tuberculose existe principalmente devido à facilidade logística encontrada na região, onde localizam-se importantes rodovias para o seguimento. A ausência de dependência espacial ocorreu devido ao baixo número de casos de tuberculose identificado por alguns métodos diagnósticos utilizados. Conclui-se que, apesar do baixo número de casos identificados, existe dependência espacial entre a ocorrência de tuberculose e a localização dos municípios.
\end{abstract}

PALAVRAS-CHAVES: GEOPROCESSAMENTO. SAÚDE PÚLICA. TUBERCULOSE. ZOONOSE.

AGRADECIMENTOS: Fundação de Amparo à Pesquisa do Estado de São Paulo (FAPESP).

ÁREA TEMÁTICA: Saúde Pública.

\footnotetext{
${ }^{1}$ Residente em Medicina Veterinária Preventiva do Programa de Residência em Área Profissional da Saúde Medicina Veterinária e Saúde da Universidade Estadual Paulista "Júlio de Mesquita Filho", Faculdade de Ciências Agrárias e Veterinárias - FCAV. E-mail: marcio_siconelli@outlook.com

2 Médico Veterinário, Mestre em Medicina Veterinária, pela Universidade Estadual Paulista "Júlio de Mesquita Filho", Faculdade de Ciências Agrárias e Veterinárias - FCAV.

${ }^{3}$ Docente do Departamento de Medicinava Veterinária Preventiva e Reprodução Animal da Universidade Estadual Paulista "Júlio de Mesquita Filho", Faculdade de Ciências Agrárias e Veterinárias - FCAV.
} 